\title{
INVESTIGATING THE CAUSES OF TRAFFIC ACCIDENTS FOR DUHOK - ZAKHO INTERNATIONAL ROAD
}

\author{
ZiYad N. Sh. Aldoski" Dilshad A. Mohammed ${ }^{* *}$ and Hamid A. Al-JAMEel ${ }^{* * *}$ \\ *Dept. of Road Construction, Duhok Technical Institute, Duhok Polytechnic University, \\ Kurdistan Region-Iraq \\ ${ }^{* *}$ Dept. of Civil Engineering, University of Duhok, Kurdistan Region-Iraq \\ ${ }^{* * *}$ Dept. of Civil Engineering, University of Kufa-Iraq
}

(Received: September 13, 2018; Accepted for Publication: November 19, 2018)

\begin{abstract}
Traffic accidents are considered as one of the main causes of death in the world. In order to reduce number of accidents, traffic safety refers to the methods and measures used to prevent road users from being killed or seriously injured. In Kurdistan, more than 1,000 inhabitants are killed in road accidents every year and about 200,000 are injured. This study focuses on investigating the reasons of accidents occurring along Duhok-Zakho international road, and identification of high accident locations (HALs) using accident number, accident rate and rate quantity control methods. Data such as the type of accident, the causes for each type, the traffic flow and geometric design have been collected for nine segments of the road from 2013 to 2016. The results indicate that the rear-end collision is the highest frequency among other types of accidents and the year 2014 has the highest number of accidents. There is an urgent need for specific countermeasures to be implemented (e.g. installing more speed limit camera, lane marking). Hence, this study has shed light on this road to find the optimum solution for such safety problem.
\end{abstract}

KEYWORDS: Traffic accidents, Black spot, Collision, Recording accidents.

\section{INTRODUCTION}

$\mathbf{G}$ enerally, Iraq is one of the dangerous countries in the number and severity of accidents because of inadequate traffic safety system (Al-Jameel, 2016). Kurdistan does not differ from Iraq in terms of safety level and lack of accident recording system and other related important information system such as causes of accident.

This study has been focused on Duhok - Zakho international road. It is one of the fundamental roads for Kurdistan Region in specific and Iraq in general, because it connects Kurdistan with the world through Ibrahim Khalil port. The road is used for trading between Turkey and Iraq. Since Turkey is the main supplier and partner for Kurdistan Region in providing goods and services, therefore the load of traffic has been increased on the road. The aim of this study is to investigate the type of accidents and the suitable countermeasure for such accidents.

\section{TRAFFIC ACCIDENTS IN IRAQ}

Limited studies have been carried out to deal with the traffic accidents in Iraq, because of the difficulties in obtaining the related required data for such study. In Iraq, the police department is the authority that is responsible for reporting the traffic accident. In fact, reporting an accident is made if a person is killed or injured and admitted to the hospital for medical treatment. Otherwise, the property damage accident may be not recorded if the drivers involved in the accident reconcile. This is the main cause of absence the right number of accidents (Al-Jameel, 2016).

Al-Taei (1997) Studied 209 accidents occurred in Mosul urban area during 1989 and 1992, covering 13 intersections, and 16 sections. Accident records were classified to three types: deep injury, light injury, and property damage only (PDO). For identification of High Accident Locations (HALs) in the city of Mosul, Al-Taei (1997) depended on critical number value (CN) and critical frequency of PDO accidents and critical equivalent number (CEN) which depended upon severity (i.e., cost, and loss of life). 
Al-Kozapanky (2000) built a predication model for Erbil City. The data used in this model represented 1780 traffic accidents for three years (1997-2000) including traffic and geometric data related to Erbil City street network. The accident prediction model can be used to predict the probability of an accident at a certain location, to compare street network with other similar locations, and to identify hazardous locations through the empirical Bayes criterion. The results show that Kurdistan and Zanko streets have the highest number of accident events.

Al-Dulemi (2002) studied traffic accidents rates on rural Iraqi highways to investigate the relationships between total fatal accident rates, the accident density on rural roads and factors such as driver behavior, vehicle speed and road geometry. The study was based on data collected from three sources which were General Police Directorate, questionnaire list, and traffic and geometric data surveys. Multiple linear regression analysis was applied by aids of SPSS computer program package to obtain the relationships, and correlation matrices to identify which elements were statistically correlated with accident occurrence. The results indicate that total accident rate is highly correlated with lane marking among other factors such as shoulder width.

Al-Taei, (2003) studied 473 accidents happened at 20 intersections and segments in Duhok City urban area over the period (19992001). Depending on critical accident rate per million vehicles the study showed that there were four hazardous intersections namely Al- Shuhada, Uper Malta, Duhok-Super Market and Ashti, and only one hazardous segment location called Malta-Sayrangah. Finally, the study concluded that, Al-Shuhada intersection was the most hazardous and it needs a serious investigation with a deep diagnosis in the future to provide safety. Malta-Sayrangah section was the most hazardous in the Duhok City urban street network needing a deep investigation by highway and traffic engineers to promote safety on it. Accident strip map for Duhok City as a result from the same study, was prepared to show the HALs.

Hardy (2007) studied the identification of HALs in Sulaimany City. Accident data were collocted from 1546 traffic accident reports over years 2002-2005. Traffic and geometric data were obtained through onsite investigation and field studies in the study area. These accidents resulted in 63 fatalities, 822 injuries, and 2286 property damage only. About 62.16 percent of the total accident occurred within main street section, 18.86 percent at intersections, 9.51 percent at local streets and 8.47 percent was an unidentified location.

Aldoski (2011) conducted a study on Duhok City street network. Accident data were obtained from 529 traffic accident reports during the years 2006-2009. For identifying different hazardous locations (Segments, intersections and local zones), various statistical, numerical methods, and the techniques of GIS were used. It was found that the average daily traffic volume, running speed and truck percentage are strongly correlated with the accidents occurrence on the street sections and intersections, while population density and distance between local zones are highly correlated with accidents occurrence on zones in the study area. Moreover, it was concluded that using GIS technique results in detecting HAL is compatible with the results obtained by the traditional methods currently used in the identification of hazardous locations in urban areas.

Al-Jameel (2016) developed an expert system to improve safety by collecting data from sources and experts in order to find the cause of accidents for each type of collisions. Then, this study recommended several suggested countermeasures (e.g. establishment of the road signs factory, Improvement of the drivers licensing procedures) to improve the safety level in Iraq.

Al-Jameel and Abdabas (2018) developed a model using GIS to reference the location of accident together with preparing suitable form to record the accident. This model intends to find the accident location more accurately.

\section{ACCIDENT DATA DOCUMENTATION}

Recently, traffic accident data is collected by responsible agencies and authorities with well specified standards and detailed procedures (Abdulhakim, 2000). In Iraq, accident report forms are filled by the traffic police officers as discussed above. This type of accident data has many deficiencies as follow: 
Table 1: Accident Report Form of Duhok Traffic Police Station

\begin{tabular}{|c|c|c|c|c|c|}
\hline Accident date & & & & & \\
\hline \multicolumn{6}{|c|}{$\begin{array}{c}\text { Police station related to } \\
\text { accidents }\end{array}$} \\
\hline Accident type & Run over & Collision & $\begin{array}{l}\text { Turn } \\
\text { over }\end{array}$ & & Others: \\
\hline \multirow[t]{7}{*}{ Accident locations } & $\begin{array}{l}\text { Road location \& lane } \\
\text { No. }\end{array}$ & Road type & Road condition & $\begin{array}{l}\text { Weather } \\
\text { condition }\end{array}$ & Accident place \\
\hline & Urban & Pavement & Dry & Clear & $\begin{array}{l}\text { On the crossing } \\
\text { line }\end{array}$ \\
\hline & Rural & Soil & Wet & Rain & $\begin{array}{l}\text { Out of crossing } \\
\text { line }\end{array}$ \\
\hline & One lane & Gravel & Greasy & Fog & $\begin{array}{c}\text { Crossing ling not } \\
\text { exist } \\
\end{array}$ \\
\hline & Two lane & Highway & $\begin{array}{l}\text { Covered } \\
\text { by snow }\end{array}$ & Dust & \\
\hline & $\begin{array}{l}\text { Greater than } \\
2 \text { lane }\end{array}$ & Tunnel & & Cloudy & \\
\hline & & Bridge & & Snow & \\
\hline \multicolumn{6}{|l|}{$\begin{array}{c}\text { Vehicle type and plate } \\
\text { number }\end{array}$} \\
\hline \multicolumn{6}{|l|}{ Driver name } \\
\hline \multicolumn{6}{|l|}{ vehicles harm } \\
\hline \multicolumn{6}{|c|}{$\begin{array}{c}\text { No. \& name of injuries and } \\
\text { deaths }\end{array}$} \\
\hline \multicolumn{6}{|l|}{ Accident cause } \\
\hline \multicolumn{6}{|l|}{ Report filing by } \\
\hline \multicolumn{6}{|c|}{ Note: Collision diagram exist in the back of paper } \\
\hline
\end{tabular}

- These data do not contain sufficient information for engineering analysis.

- The filling form data is inadequate in terms of accident location, weather condition, victim record, etc.

- Some minor accidents were not recorded because the drivers agreed with each other without contacting the police administration.

In the same time, obtaining the accident data was a difficult process because of the existing routine problems, decision maker's administrations especially due to the time restraint of the study, comparing with other countries that have computer stored accident information data bank system and can be very easy to retrieve by safety research workers.

Accident reports collected from traffic office include the following information. A form as shown in table 1 was used by traffic office for collecting accident data.

1- Information about the accident date (i.e., day, month, year, and hour), the accident location (i.e., street and intersection name), the weather and the road surface condition (i.e., dry, wet, icy, misty, snow, windy.... etc.), the accident type and the accident severity such as, collision and type of collision, over turn, run over. 
2. Information about accident classes such as, the number of persons killed, injured and property damage only.

3- Site plan and diagram showing the accident.

\section{STUDY AREA DESCRIPTION}

This study considered Duhok - Zakho International highway. This road has been chosen because it consists of a complete street network system with a variety of land use (e.g., residential, industrial, commercial, administer, recreational zones).

The road connects Zakho district with Sumel district and Duhok all the way to Mosul. The road serves the transportation of many public governmental projects and non-governmental companies in daily basis such as Zakho University, local shops, car inspection and storages for local companies (Duhok Governorate-Directorate of Guide and information Center, 2016). This variety of vehicle types rises the causes of losing control in driving and result accidents (Duhok GovernorateDirectorate of traffic / Duhok. Also, the road was out of service temporary due to reconstruction work. Finally, Duhok - Zakho is consider as an international road, where drivers from Turkey and Syria use it for transportations and traveling goods (please see figure 1).

One of the main issues of KRG (Kurdistan Region Government) drivers and traffic rules is that, reckless driving and ignoring the traffic rules. Most of the roads do not have lines mark lanes and even if there are, drivers barely follow it. When drivers do not make safe lane changes properly, it often leads to a car accident. Distracted drivers are the top cause of car accidents. A distracted driver is a motorist that diverts his or her attention from the road, usually due to :1- Talk on a cell phone 2- Send a text message 3- Eat food 4- Speak with passenger. Therefore, the aim of this study is to investigate the accidents causes to avoid occurring accidents and reducing loss of lives and properties.

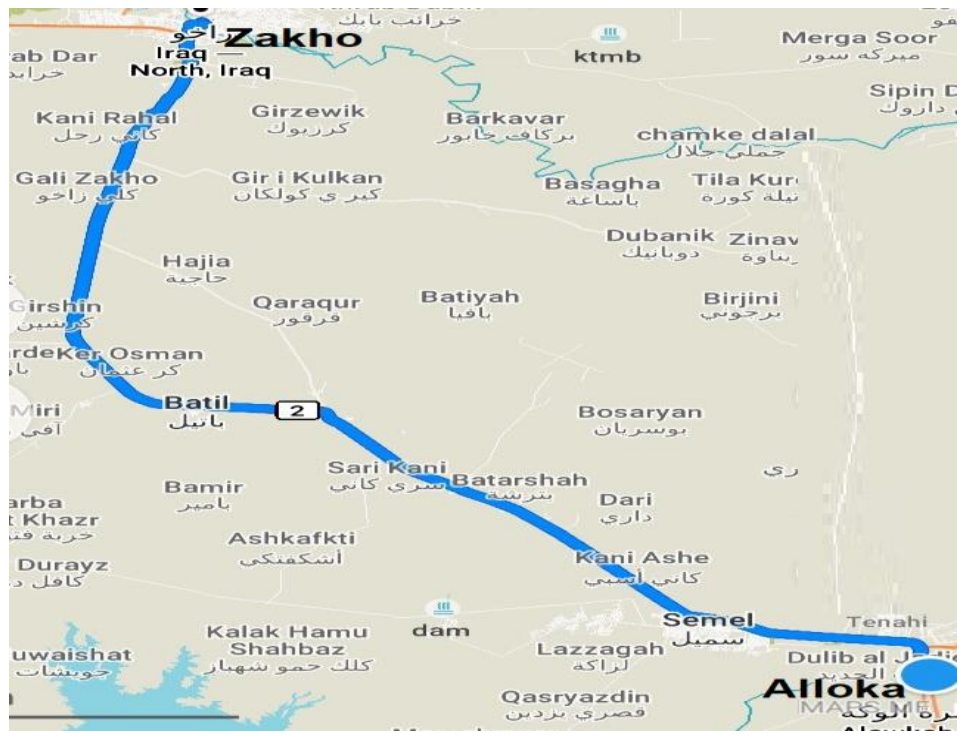

Fig. (1): Duhok - Zakho International road location

\section{DATA COLLECTION}

The main three types of data which collected for achieving the purpose of this study were accident data, traffic data and geometric data, Accident data are taken from 331 traffic accident reports during the years 2013-2016, these data were recorded and stored in directorate of traffic at Duhok, Sumel, Zakho Valley and Zakho City.
Traffic and geometric data are obtained through direct measurement from field in the study area.

The accident data are collected from traffic office, as illustrated in table 2 . The data were entered to an excel sheet to categories the type and cause of accidents. The road was divided into 9 sections and a camera was installed on each section for one hour to record the number of vehicle and average speed used on the road. 
To study the road surface characteristic such as dry and wet, five months from (November 20, 2017) to (April 23, 2017) including different seasons. In winter, the road is mostly wet because of snow or rain and in spring the road is mostly dry.

Table 2: Number of accidents registered in Directorate of Traffic.

\begin{tabular}{cccccc}
\hline Type of Accident Severity & $\mathbf{2 0 1 3}$ & $\mathbf{2 0 1 4}$ & $\mathbf{2 0 1 5}$ & $\mathbf{2 0 1 6}$ & Total \\
\hline Property Damage Only & 37 & 82 & 41 & 39 & 199 \\
\hline Injury & 23 & 31 & 19 & 38 & 111 \\
\hline Fatal & 5 & 6 & 4 & 6 & 21 \\
\hline Total & 65 & 119 & 64 & 83 & \\
\hline
\end{tabular}

\subsection{Traffic Data}

To give a comprehensive picture for the nature of traffic flow characteristic along the road under study, the traffic volume data was collected during the working days and at peak hour. ADT was considering 16 hours of service (Aldoski, 2011).
This is because of the absence of the traffic data at local authorities. Video camera was setup at a vantage place where invisible by the drivers and has a good visibility of traffic movement. Traffic data shown in table 3.

Table 3: Traffic Data for Duhok - Zakho Road Sections

\begin{tabular}{|c|c|c|c|c|c|c|c|c|}
\hline \multicolumn{2}{|c|}{ Road Section } & \multirow{2}{*}{$\begin{array}{c}\text { Passenge } \\
\text { r Car }\end{array}$} & \multirow[t]{2}{*}{ Taxi } & \multirow[t]{2}{*}{ Truck } & \multirow[t]{2}{*}{ Buss } & \multirow{2}{*}{$\begin{array}{l}\text { Volume } \\
\text { (pcu/hr) }\end{array}$} & \multirow{2}{*}{$\begin{array}{c}\text { ADT } \\
\text { (puc/day }\end{array}$} & \multirow{2}{*}{$\begin{array}{c}\text { Averag } \\
\text { e }\end{array}$} \\
\hline From & To & & & & & & & \\
\hline Alloka & Tanahi & 2216 & 760 & 224 & 8 & 3,324 & 53,184 & 82 \\
\hline Tanahi & Sumel Stadium & 2228 & 664 & 208 & 16 & 3,228 & 51,648 & 75 \\
\hline Sumel Stadium & Marina Compex & 1420 & 232 & 272 & 20 & 2,090 & 33,440 & 80 \\
\hline Marina Compex & Duhok Airport & 882 & 108 & 96 & 3 & 1,139 & 18,216 & 86 \\
\hline Duhok Airport Way & Batel & 624 & 124 & 100 & 20 & 928 & 14,848 & 72 \\
\hline Batel & Girshin & 576 & 108 & 147 & 6 & 914 & 14,616 & 87 \\
\hline Girshin & Zakho Tunnel & 256 & 16 & 216 & 0 & 596 & 9,536 & 110 \\
\hline Zakho Tunnel & Hassan Ava & 503 & 104 & 0 & 4 & 613 & 9,808 & 81 \\
\hline Hassan Ava & Zakho & 712 & 128 & 18 & 20 & 897 & 14,352 & 75 \\
\hline
\end{tabular}

Moreover, geometric design information are collected for the analysis purpose. The data type of streets are divided or un-divided, street length and width. In this study, street length and width is obtained by two methods:

- The satellite image technique: by using Google Earth professional version 5.2.1.1329 Beta from Internet Service Connection.

- Field survey by tape: using 50-meter tape in such streets which have short length as shown in table 4.

\subsection{Characteristics Of Accidents On Duhok - Zakho Street}

In this section, the characteristics of DuhokZakho highway in term of highest of accident locations are discussed. Based on the distribution of accidents on the road, the total reported number of accidents were 331 accidents over period (2013-2016). The accidents collected from these sections are 44 fatalities, 325 injuries, and 430 property damages only as shown in table 5 . 
Table 4: Geometric data for road sections under study.

\begin{tabular}{ccccc}
\hline \multicolumn{2}{c}{ Road Section } & Section No. & Length $(\mathbf{k m})$ & \multirow{2}{*}{ Width $(\mathbf{m})$} \\
\hline From & To & & & \\
\hline Alloka & Tanahi & 1 & 2.5 & 14.4 \\
\hline Tanahi & Sumel Stadium & 2 & 4.31 & 14.4 \\
\hline Sumel Stadium & Marina Compex & 3 & 11.23 & 14.4 \\
\hline Marina Compex & Duhok Airport Way & 4 & 2.68 & 10.8 \\
\hline Duhok Airport Way & Batel & 5 & 6.33 & 7.2 \\
\hline Batel & Girshin Intersection & 6 & 5.43 & 7.2 \\
\hline Girshin Intersection & Zakho Tunnel & 7 & 6.5 & 7.2 \\
\hline Zakho Tunnel & Hassan Ava & 8 & 4.61 & 10.8 \\
\hline Hassan Ava & Zakho & 9 & 5.9 & 14.4 \\
\hline
\end{tabular}

Table 5: Accident Severity during Study Period

\begin{tabular}{|c|c|c|c|c|c|}
\hline \multicolumn{6}{|c|}{ Accident Severity } \\
\hline \multirow[t]{2}{*}{ Year } & \multicolumn{2}{|c|}{ No. of Damage Vehicles } & \multirow{2}{*}{$\begin{array}{l}\text { No. of } \\
\text { Injuries }\end{array}$} & \multirow{2}{*}{$\begin{array}{l}\text { No. of } \\
\text { Killed }\end{array}$} & \multirow{2}{*}{$\begin{array}{c}\text { Accident } \\
\text { Severity \% }\end{array}$} \\
\hline & Passenger & Trucks & & & \\
\hline 2013 & 51 & 35 & 161 & 15 & 9.32 \\
\hline 2014 & 96 & 74 & 84 & 12 & 14.29 \\
\hline 2015 & 59 & 12 & 48 & 9 & 18.75 \\
\hline 2016 & 61 & 42 & 32 & 8 & 25.00 \\
\hline Total & 267 & 163 & 325 & 44 & \\
\hline
\end{tabular}

Table 5 shows that the accident severity in case of number of fatal from the total number of accident which increases from $9.32 \%$ in 2013 to $25 \%$ in 2016 . This percentage shows high severity with time comparing with other countries such as Japan (2.5\%) (Al-Jameel, 2016). This means the severity is higher by ten times for Japan.
From the total accident reports collected the first three road sections having highest accident frequencies is Hasan Ava, Marina Complex, and Girshin Intersection Section as shown in Figure 2. This is because of inappropriate location of the secondary arterial streets that linked with the main street (i.e. Duhok - Zakho).

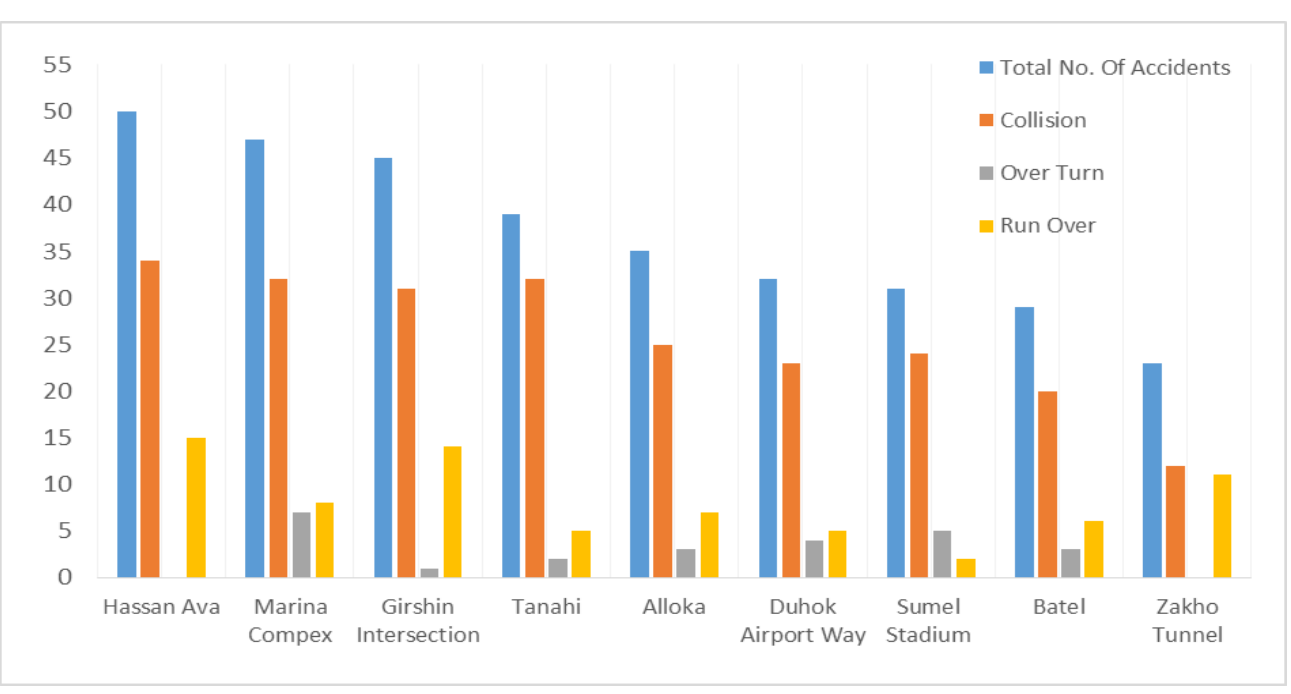

Fig. (2): Location Ranking According to the Highest Accident Frequencies based on Accident Type 
Year 2014 is the highest number of accident among other years as illustrated in table 2, that is because the apparent increase in the number of vehicles, the displacement of refugees from neighboring areas as Shingal, and the entry of non-governmental organizations into the area have led to increased traffic volume on the Road, leading to an increase in the number of accidents.
Classification of accidents by type into collision, over turn and run over accidents is shown in table 5, where collision accidents formed the majority of total accidents which is $70.4 \%$ of total accidents, while over turn is less. This is normal even the rate of overturn and run over are $7.6 \%$ and $22 \%$ respectively, because it is rural road with very high speed drivers specially teenagers and during taking over maneuvers.

Table 6: Type of accident per year

\begin{tabular}{ccccc}
\hline Year & Collision & Over Turn & Run Over & Total No. of \\
\hline 2013 & 47 & 4 & 14 & 65 \\
\hline 2014 & 86 & 7 & 26 & 119 \\
\hline 2015 & 41 & 8 & 15 & 64 \\
\hline 2016 & 59 & 6 & 18 & 83 \\
\hline & 233 & 25 & 73 & 331 \\
\hline
\end{tabular}

Figure 3 indicates that the rear end collisions represents the highest percentage among other types of accidents. Whereas, the left turn accidents come in the second stage in the percentage among other types of collision. It is normal for the rear end accidents, but the left turn accidents have a high percentage, and this happens because there is no curbed median between two sides in many sections, which gives the drivers the opportunity to turn left in many dangerous places.

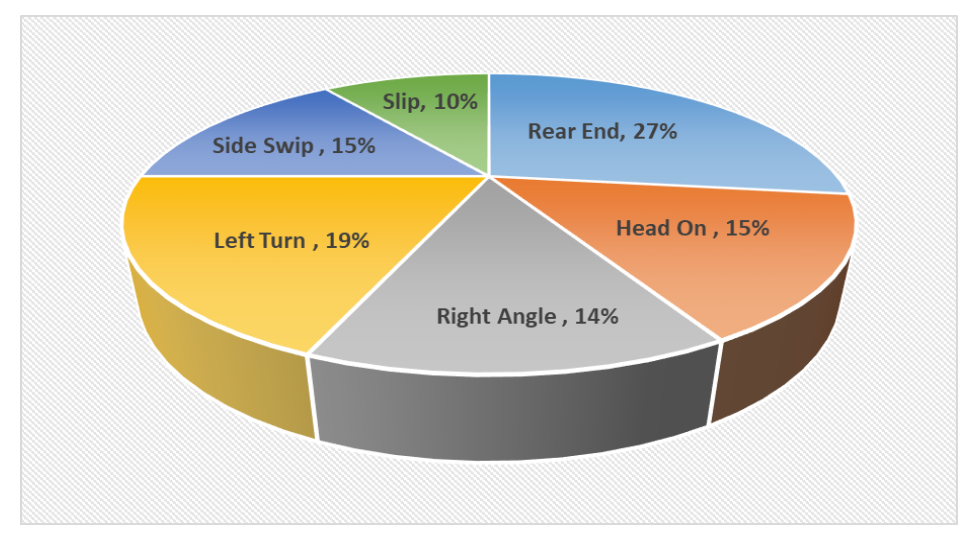

Fig. )3): Accident Rate by type of Collision

The distribution of accidents along different months of year is given in table 7. It is shown that the highest number of accidents occurred in January, which is 40 accidents. This is because the climatic conditions during this month, represented by rain, snow and sometimes frost which affect the street surfaces. While sometimes the foggy weather affects the vision of drivers. All these factors lead to unsafe driving in this area during winter season. 
Table 7: Total accident for each month for different years

\begin{tabular}{|c|c|c|c|c|c|c|c|c|c|c|c|c|}
\hline Year & 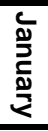 & 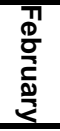 & $\begin{array}{l}3 \\
\frac{3}{0} \\
\frac{3}{3}\end{array}$ & $\stackrel{D}{\frac{D}{3}}$ & 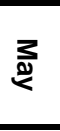 & ড్ & 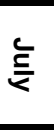 & 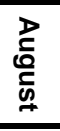 & 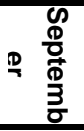 & 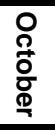 & 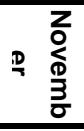 & 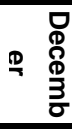 \\
\hline 2013 & 2 & 10 & 12 & 3 & 2 & 3 & 4 & 13 & 11 & 5 & 0 & 0 \\
\hline 2014 & 6 & 11 & 8 & 14 & 14 & 11 & 10 & 13 & 2 & 11 & 9 & 10 \\
\hline 2015 & 18 & 1 & 2 & 7 & 1 & 3 & 3 & 5 & 4 & 10 & 7 & 3 \\
\hline 2016 & 14 & 11 & 13 & 7 & 7 & 4 & 8 & 4 & 7 & 2 & 1 & 5 \\
\hline Total & 40 & 33 & 35 & 31 & 24 & 21 & 25 & 35 & 24 & 28 & 17 & 18 \\
\hline
\end{tabular}

Table 8 indicates the road surface conditions at which accidents are occurred whether the surface is dry or wet, most of accidents occurred in dry surface of the road because most of the time in the year the road is dry.

Table 8: Distribution of Accidents by Road Surface (Dry - Wet)

\begin{tabular}{cccc}
\hline No. & Year & Dry & Wet \\
\hline 1 & 2013 & 59 & 6 \\
\hline 2 & 2014 & 104 & 14 \\
\hline 3 & 2015 & 54 & 11 \\
\hline 4 & 2016 & 68 & 15 \\
\hline
\end{tabular}

To identifying and prioritizing high accident locations (HALs) along Duhok - Zakho road sections, the criteria were based on several methods used individually or in combination with identifying HALs on street section, these criteria were (accident number, accident rate and rate quantity control).

The detail analysis for the total number of accidents in year 2013 is shown in tables 9. While for the years 2014, 2015 and 2016 is shown in table 10,11 , and 12 respectively.

Marina Complex section is considered as first HALs during study time period, Aloka, Tanahi and Girshin Intersection identified as second dangerous sections, while other road sections was safe and there was no dangerous location on it.

Table 9: Identification of Hazardous Street Section in Study Area 2013

\begin{tabular}{|c|c|c|c|c|c|c|c|c|c|c|c|c|}
\hline \multirow{2}{*}{$\sum_{i}^{\circ}$} & \multirow[t]{2}{*}{ Name of street } & \multirow{2}{*}{$\begin{array}{l}0 \\
2 \\
\frac{0}{8} \\
0\end{array}$} & \multirow{2}{*}{ 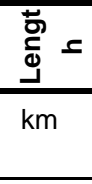 } & \multirow{2}{*}{$\begin{array}{c}\begin{array}{c}5 \\
\& \\
\text { veh/da } \\
y\end{array} \\
\end{array}$} & \multicolumn{3}{|c|}{ Accident No. method } & \multirow{2}{*}{$\begin{array}{c}\text { Acciden } \\
\text { t Rate } \\
\text { Acc./MV } \\
\mathrm{KM}>\end{array}$} & \multicolumn{3}{|c|}{$\begin{array}{c}\text { Rate Quality Control } \\
\text { method }\end{array}$} & \multirow{2}{*}{ 咅 } \\
\hline & & & & & $\begin{array}{l}2 a> \\
14.4\end{array}$ & $\begin{array}{l}>\mathrm{CN}= \\
12.14\end{array}$ & $\begin{array}{c}\text { Acc } / \mathrm{km}> \\
2.63\end{array}$ & & $\mathrm{~m}$ & $\mathrm{Rc}$ & $\begin{array}{l}\text { RcF } \\
>1\end{array}$ & \\
\hline 1 & Alloka & 1 & 2.5 & 53,184 & 6 & 6 & 2.40 & 0.12 & 48.53 & 24.7 & 0.00 & \\
\hline 2 & Tanahi & 2 & 4.31 & 51,648 & 13 & 13 & 3.02 & 0.16 & 81.25 & 41.0 & 0.00 & \\
\hline 3 & Sumel Stadium & 3 & 11.2 & 33,440 & 9 & 9 & 0.80 & 0.07 & 137.07 & 68.9 & 0.00 & \\
\hline 4 & Marina Compex & 4 & 2.68 & 18.216 & 9 & 9 & 3.36 & 0.51 & 17.82 & 9.46 & 0.05 & \\
\hline 5 & Duhok Airport Wav & 5 & 6.33 & 14,848 & 7 & 7 & 1.11 & 0.20 & 34.31 & 17.6 & 0.01 & \\
\hline 6 & Batel & 6 & 5.43 & 14,616 & 8 & 8 & 1.47 & 0.28 & 28.97 & 14.9 & 0.02 & \\
\hline 7 & Girshin Intersection & 7 & 6.5 & 9.536 & 4 & 4 & 0.62 & 0.18 & 22.62 & 11.8 & 0.01 & \\
\hline 8 & Zakho Tunnel & 8 & 4.61 & 9.808 & 8 & 8 & 1.74 & 0.48 & 16.50 & 8.81 & 0.05 & \\
\hline 9 & Hassan Ava & 9 & 5.9 & 14.352 & 1 & 1 & 0.17 & 0.03 & 30.91 & 15.9 & 0.00 & \\
\hline
\end{tabular}


Table 10: Identification of Hazardous Street Section in Study Area 2014

\begin{tabular}{|c|c|c|c|c|c|c|c|c|c|c|c|c|}
\hline \multirow{2}{*}{$\sum_{\text {i }}^{\circ}$} & \multirow[t]{2}{*}{ Name of street } & \multirow{2}{*}{ 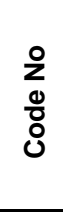 } & \multirow{2}{*}{ 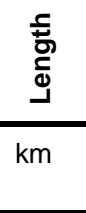 } & 占 & \multicolumn{3}{|c|}{ Accident No. method } & \multirow{2}{*}{$\begin{array}{c}\begin{array}{c}\text { Acciden } \\
\text { t Rate } \\
\text { method }\end{array} \\
\mathrm{Acc} . / \mathrm{MV} \\
\mathrm{KM}>0.8 \\
\end{array}$} & \multicolumn{3}{|c|}{$\begin{array}{c}\text { Rate Quality Control } \\
\text { method }\end{array}$} & \multirow{2}{*}{$\overrightarrow{\underline{\underline{I}}}$} \\
\hline & & & & veh/day & $\begin{array}{l}2 a> \\
26.4\end{array}$ & $\begin{array}{c}>\mathrm{CN}= \\
19.7\end{array}$ & $\begin{array}{c}\text { Acc } / \mathrm{km}> \\
4.81 \\
\end{array}$ & & $\mathrm{~m}$ & Rc & $\begin{array}{c}\text { RcF } \\
>1\end{array}$ & \\
\hline 1 & Alloka & 1 & 2. & 53,184 & 23 & 23 & 9.20 & 0.47 & 48.53 & 24.7 & 0.02 & \\
\hline 2 & Tanahi & 2 & 4. & 51.648 & 16 & 16 & 3.71 & 0.20 & 81.25 & 41.0 & 0.00 & \\
\hline 3 & Sumel Stadium & 3 & 11 & 33,440 & 8 & 8 & 0.71 & 0.06 & 137.07 & 68.9 & 0.00 & \\
\hline 4 & Marina Compex & 4 & 2. & 18,216 & 27 & 27 & 10.07 & 1.52 & 17.82 & 9.46 & 0.16 & \\
\hline 5 & Duhok Airport Wav & 5 & 6. & 14,848 & 8 & 8 & 1.26 & 0.23 & 34.31 & 17.6 & 0.01 & \\
\hline 6 & Batel & 6 & 5. & 14,616 & 5 & 5 & 0.92 & 0.17 & 28.97 & 14.9 & 0.01 & \\
\hline 7 & Girshin Intersection & 7 & 6. & 9.536 & 11 & 11 & 1.69 & 0.49 & 22.62 & 11.8 & 0.04 & \\
\hline 8 & Zakho Tunnel & 8 & 4. & 9,808 & 1 & 1 & 0.22 & 0.06 & 16.50 & 8.81 & 0.01 & \\
\hline 9 & Hassan Ava & 9 & 5. & 14,352 & 20 & 20 & 3.39 & 0.65 & 30.91 & 15.9 & 0.04 & \\
\hline \multicolumn{12}{|c|}{ Table 11: Identification of Hazardous Street Section in Study Area 2015} & \\
\hline \multirow{2}{*}{$\sum_{i}^{\dot{j}}$} & \multirow[t]{2}{*}{ Name of street } & \multirow{2}{*}{ है } & \multirow{2}{*}{\begin{tabular}{l}
0 \\
\hdashline \\
\hdashline \\
\hdashline
\end{tabular}} & $\frac{5}{<}$ & \multicolumn{3}{|c|}{ Accident No. method } & $\begin{array}{c}\text { Accident } \\
\text { Rate }\end{array}$ & \multicolumn{3}{|c|}{$\begin{array}{c}\text { Rate Quality Control } \\
\text { method } \\
\end{array}$} & \\
\hline & & & & veh/day & $\begin{array}{l}2 a>1 \\
4.22 \\
\end{array}$ & $\begin{array}{c}>\mathrm{CN}=1 \\
2.0 \\
\end{array}$ & $\begin{array}{c}\text { Acc } / \mathrm{km}>2 \\
.59\end{array}$ & $\begin{array}{c}\text { Acc./MVK } \\
M>0.46\end{array}$ & $\mathrm{~m}$ & $\mathrm{Rc}$ & $\begin{array}{c}\text { RcF> } \\
1\end{array}$ & \\
\hline 1 & Alloka & 1 & 2.5 & 53.184 & 5 & 5 & 2.00 & 0.10 & 48.53 & 24.73 & 0.00 & \\
\hline 2 & Tanahi & 2 & 4.31 & 51.648 & 6 & 6 & 1.39 & 0.07 & 81.25 & 41.06 & 0.00 & \\
\hline 3 & Sumel Stadium & 3 & 11.23 & 33.440 & 10 & 10 & 0.89 & 0.07 & 137.07 & 68.95 & 0.00 & \\
\hline 4 & Marina Compex & 4 & 2.68 & 18.216 & 9 & 9 & 3.36 & 0.51 & 17.82 & 9.46 & 0.05 & \\
\hline 5 & Duhok Airport Wav & 5 & 6.33 & 14,848 & 3 & 3 & 0.47 & 0.09 & 34.31 & 17.64 & 0.00 & \\
\hline 6 & Batel & 6 & 5.43 & 14.616 & 8 & 8 & 1.47 & 0.28 & 28.97 & 14.99 & 0.02 & \\
\hline 7 & Girshin Intersection & 7 & 6.5 & 9.536 & 5 & 5 & 0.77 & 0.22 & 22.62 & 11.84 & 0.02 & \\
\hline 8 & Zakho Tunnel & 8 & 4.61 & 9.808 & 5 & 5 & 1.08 & 0.30 & 16.50 & 8.81 & 0.03 & \\
\hline 9 & Hassan Ava & $\underline{9}$ & 5.9 & 14.352 & 13 & 13 & 2.20 & 0.42 & 30.91 & 15.95 & 0.03 & \\
\hline
\end{tabular}

Table 12: Identification of Hazardous Street Section in Study Area 2016

\begin{tabular}{|c|c|c|c|c|c|c|c|c|c|c|c|}
\hline \multirow{2}{*}{$\sum_{\dot{j}}^{\dot{j}}$} & \multirow[t]{2}{*}{ Name of street } & \multirow{2}{*}{$\begin{array}{l}0 \\
2 \\
0 \\
0 \\
0\end{array}$} & \multirow{2}{*}{$\frac{\stackrel{5}{5}}{\stackrel{5}{\Phi}}$} & \multirow{2}{*}{$\begin{array}{l}\frac{5}{6} \\
\text { veh/day }\end{array}$} & \multicolumn{3}{|c|}{ Accident No. method } & \multirow{2}{*}{$\begin{array}{c}\begin{array}{c}\text { Acciden } \\
\text { t Rate } \\
\text { method }\end{array} \\
\mathrm{Acc} . / \mathrm{MV} \\
\mathrm{KM}>0.6\end{array}$} & \multicolumn{3}{|c|}{$\begin{array}{l}\text { Rate Quality Control } \\
\text { method }\end{array}$} \\
\hline & & & & & $\begin{array}{l}2 a> \\
18,4 \\
\end{array}$ & $\begin{array}{l}>\mathrm{CN}= \\
14.72 \\
\end{array}$ & $\begin{array}{c}\text { Acc } / \mathrm{km}> \\
3.35 \\
\end{array}$ & & $\mathrm{~m}$ & Rc & $\begin{array}{l}\mathrm{RcF} \\
>1\end{array}$ \\
\hline 1 & Alloka & 1 & 2.5 & 53,184 & 1 & 1 & 0.40 & 0.02 & 48.53 & 24.7 & 0.00 \\
\hline 2 & Tanahi & 2 & 4.31 & 51,648 & 4 & 4 & 0.93 & 0.05 & 81.25 & 41.0 & 0.00 \\
\hline 3 & Sumel Stadium & 3 & 11.2 & 33,440 & 4 & 4 & 0.36 & 0.03 & 137.07 & 68.9 & 0.00 \\
\hline 4 & Marina Compex & 4 & 2.68 & 18,216 & 2 & 2 & 0.75 & 0.11 & 17.82 & 9.46 & 0.01 \\
\hline 5 & Duhok Airport Way & 5 & 6.33 & 14,848 & 14 & 14 & 2.21 & 0.41 & 34.31 & 17.6 & 0.02 \\
\hline 6 & Batel & 6 & 5.43 & 14.616 & 8 & 8 & 1.47 & 0.28 & 28.97 & 14.9 & 0.02 \\
\hline 7 & Girshin Intersection & 7 & 6.5 & 9,536 & 24 & 24 & 3.69 & 1.06 & 22.62 & 11.8 & 0.09 \\
\hline 8 & Zakho Tunnel & 8 & 4.61 & 9,808 & 10 & 10 & 2.17 & 0.61 & 16.50 & 8.81 & 0.07 \\
\hline 9 & Hassan Ava & 9 & 5.9 & 14,352 & 16 & 16 & 2.71 & 0.52 & 30.91 & 15.9 & 0.03 \\
\hline
\end{tabular}

\section{CONCLUSIONS AND RECOMMENDATIONS}

The main conclusions come up with this study are summarized as:

1. There is inadequate safety system to record and investigate the number and cause of accident. New system for traffic accidents is required to improve our current system.
2. Duhok - Zakho international road suffers from the high rate of accidents due to the lack of safety considerations as indicated in this paper.

3. The collected data indicate several types of accidents occurring on Duhok - Zakho road with different percentages. These percentages are $27 \%$ for rear end, $19 \%$ left turn, $15 \%$ for both side swip and head on, $14 \%$ for right angle, and $10 \%$ for slip. 
4. Installed number of speed-limiting cameras, especially fixed camera to force drivers to reduce speed.

5. Open a special lane for trucks and heavy vehicles so that the speed limit for this lane is less than the speed of ordinary lane, because the proportion of trucks is high on this road and contribute significantly to the occurrence of traffic accidents, where $37.9 \%$ of accidents on this road trucks were involved.

6. Decreasing the possible places for left-turning by building median and building side protection for the road by putting guardrail especially in elevated areas to protect vehicles.

7. Considering more factors (e.g. road geometry) and using statistical analysis techniques.

\section{SUGGESTED IMPROVEMENTS}

Having reported accident surveys in this road, several solutions are proposed as:

1. Adopting referencing system to document accidents to the actual location using GIS system by traffic police offices as mentioned by AlJameel and Abadabas (2018).

2. Improving the safety form by adding referencing points along the road under study and then transfer these information into GIS system as reported by Al-Jameel and Abadabas (2018).

3. Installing specialized traffic camera to record the daily traffic in addition to investigate the traffic accidents.

\section{REFERENCES}

- Abdulhakim. O.S. Al-Kosapanky.(2000) "Development of Accident Prediction Models for Arbil Urban Area.", Ph.D. Thesis, College of Engineering, Civil Engineering Department, University of Baghdad

- Al-Taei A.M. (2003) "Identification of HighAccident Locations in Duhok City Urban Area",
Journal of Duhok University, Scientific and Academic Volume 6, No. 1.

- Al- Taei A.M. (1997) "Identification of HighAccident Locations on Mosul Citytreets", AlRafidain Engineering journal, Volume 5, No. 2, University of Mosul.

- Aldoski, Ziyad N. Sh. (2011). "Traffic Accident Statistical modeling in Duhok City Street Network and the use of GIS techniques", Salahadin University, Erbil.

- Al-Dulemi, Ahmad Saleem A. Sh. (2002), "Development of Traffic Accident Predication Models on Rural Highways in Iraq", M.Sc. Thesis, College of Engineering, Civil Engineering Department, University of $\mathrm{Al}-$ Mustansiria.

- Al-Jameel, H. (2016). Reducing the Number of Accidents in Iraq by Using Expert System. Journal of Babylon University, Engineering Sciences, Vol.24 (4).

- Al-Jameel, H. and Abdabas, H. (2018). Identifying Black Spot Locations at Karbala City by Using GIS System. International Journal of Civil Engineering and Technology (IJCIET), Vol.9(4), pp. 933-938.

- Hardy, K. K. (2007) "Development of Traffic Safety Program in Sulaimany City Urban Network", M.Sc. Thesis, College of Engineering, Civil Engineering Department, University of Sulaimany.

- International Transport Forum (2008). "Towards Zero, Ambitious Road Safety Targets and the Safe System Approach". OECD. Archived from the original on 15 May 2008. Retrieved 26 January 2012.

- National Research Council, Transportation Research Board, "Highway Capacity Manual", HCM2000.

- Weymont, Deborah, and Tina Rae. (2006) Supporting Young People Coping with Grief, Loss and Death. London: Paul Chapman. 